\title{
In-Vitro and In-Vivo Anti-Inflammatory and Analgesic Activity of Bixa orellana Linn Leaf Extracts
}

\author{
Radhika B*, Nasreen Begum, Srisailam. K
}

Vaageshwri College of Pharmacy, Timmapur, Karimnagar, Telangana, India.

*Corresponding author: Radhika B, Vaageshwri College of Pharmacy, Timmapur, Karimnagar, Telangana, India, E-mail: radhiyre@gmail.com

Received: March 01, 2017; Revised: March 16, 2016; Published: April 10, 2017

Copyright: (C2017 Radhika B, et al. This is an open-access article distributed under the terms of the Creative Commons Attribution License, which permits unrestricted use, distribution, and reproduction in any medium, provided the original author and source are credited. The article has been previewed and authenticated by the Authors before sending the publication for print. The Journal, Editor and the Editorial Board are not entitled or liable to either justify or responsible for inaccurate and misleading data if any. It is the sole responsibility of the Author concerned.

Citation: Radhika B, Begum N, Srisailam K. In-Vitro and In-Vivo Anti-Inflammatory and Analgesic Activity of Bixa orellana Linn Leaf Extracts. Int J Pharm Pharmacol 2017; 1: 108. dio: $\underline{10.31531 / 2581-3080.1000108}$

\begin{abstract}
Objective: The objective of the present study is to investigate the Anti-inflammatory and analgesic activity of Bixa orellana Linn. (Bixaceae) leaves.

Methods: The dried leaf powder was subjected to successive Soxhlet extraction using petroleum ether, chloroform, ethyl acetate, methanol and water extracts were investigated for anti-inflammatory activity and analgesic activity in Wistar rats using standard methods. The acute toxicity studies are done and it gives that the animal is alive for $24 \mathrm{~h}$ up to $1000 \mathrm{mg} / \mathrm{kg}$. The volume of hind paw is measured prior and after inducing the inflammation by using plethysmometer. The amount of inflammation in untreated animals and animals treated with test drugs was measured.

Results: The results obtained revealed that the petroleum ether extract showed highest activity at dose level of $250 \mathrm{mg} / \mathrm{kg}$ at $2 \mathrm{~h}$. If the inflammation in the treated animals is less than that in untreated animals, then the drug is considered to possess anti-inflammatory activity when compare to standard drug, Diclofenac sodium and arachis oil as vehicle and control for the extract. The analgesic activity of various extracts of leaves of Bixa orellana was evaluated by tail immersion method. The results revealed that maximum activity was showed by methanolic extract $(12.4 \mathrm{sec})$ at a dose of $500 \mathrm{mg} / \mathrm{kg}$ at 120 min after administration.
\end{abstract}

Keywords: Annatto, Bixa orellana, Bixaceae, Diclofenac sodium, analgesic

\section{Introduction}

Inflammation is a process by which the body's white blood cells and chemicals protect us from infection and foreign substances, such as bacteria and viruses. When inflammation occurs, chemicals from the body's white blood cells are released into the blood or affected 
tissues in an attempt to rid the body of foreign substances. This release of chemicals increases the blood flow to the area and may result in redness and warmth. Some of the chemicals cause leakage of fluid into the tissues, resulting in swelling. The inflammatory process may stimulate nerves and cause pain [1].

Pain is defined by medical researchers as a subjective conscious experience. The presence or absence of pain even in another human is only verifiable by their report; "Pain is whatever the experiencing person says it is, and exists whenever he says it does. Currently, it is not possible to prove whether an animal is in pain or not, however it can be inferred through physical and behavioral reactions, so veterinary science assumes that if something would be painful for a human, then it would be painful for an animal, and analgesics are used preemptively, where possible [1].

An analgesic (colloquially known as a painkiller) is any member of the diverse group of drugs used to relieve pain (achieve analgesia). The word analgesic derives from Greek an- ("without") and -algia ("pain"). Analgesic drugs act in various ways on the peripheral and central nervous systems; they include paracetamol (acetaminophen) [2].

Bixa belongs to family Bixaceae and is represented by a single species Bixa orellana. One of the plants having many medicinal uses in traditional system of medicine is Bixa orellana. It is a shrub or bushy tree which ranges from 3 to $10 \mathrm{~m}$ in height [3]. Both roots and leaves are used for treating sore throats, jaundice, dysentery, gonorrhea, liver diseases, anti-inflammatory and antipyretic agent [4]. Previously published scientific reports proven that the plant as reported to process antivenom, antimicrobial, anticonvulsant, analgesic, antidiarrheal, enzyme inducing, hypoglycemic and antimutagenic activity. The plant is used in traditional Filipino cooking as a coloring agent. It is also used in coloring butter, margarine, cheese, beverages, meat and fish products. The Bixa dye known also as annatto dye, is extracted from the outer covering of the seeds of Bixa orellana [5].

The review of the scientific literature did not reveal any information on the anti- inflammatory studies of this plant. In this investigation, an attempt was made to assess the efficacy of this indigenous plant for its antiinflammatory activity in terms of the volume of hind paw is measured prior and after inducing the inflammation by using plethysmometer.

The review of the scientific literature revealed that the plant Bixa orellana has the Analgesic activity [6] where as my work is on Tail immersion method.

\section{Materials and Methods}

\section{Procurement of Chemicals}

Diclofenac sodium was obtained from Mangalam Drugs and Pharmaceuticals Ltd, Wapi, Gujarat. paracetmol was obtained from Wockhardt Laboratories, Aurangabad. The solvent used were of Laboratory grade obtained from EMerck Ltd., Mumbai. Groundnut or Arachis oil was purchased from local market. All other chemicals of highest available purity were obtained from HiMedia Laboratories, Mumbai.

\section{Collection of Plant Material}

The leaves of $B$. orellana were collected from the wild growing tree in the Botanical Garden, Biotechnology Department in Kakatiya University, Warangal, India. Identification and confirmation was performed a qualified taxonomist. It was collected in the year 2006. A specimen was deposited in the institutional herbarium. The collected plant material was made thoroughly free from any foreign organic matter. Leaves were separated, shade dried and powdered with laboratory mixer and sieved.

\section{Preparation of Extract}

The weighed (70 g) leaf powder was kept to successive Soxhlet extraction using petroleum ether $\left(60-80^{\circ} \mathrm{C}\right)$, chloroform, ethyl acetate, methanol and water, the solvent should be taken $3 / 4^{\text {th }}$ of the round bottomed flask, each for 6 hours and each solvent should be extracted single time. The obtained solvent extracts were concentrated and dried in desiccators [7].

\section{Animals}


The healthy Wistar rats of either sex, approximately the same age and weighing about 150-180 g used for the study were obtained from Mahaveer Enterprises, Hyderabad. They were fed with standard chow diet and water required. The animals were housed in polypropylene cages maintained under standard environmental conditions $(12 \mathrm{~h}$ light $/ 12 \mathrm{~h}$ dark cycle; $25 \pm 3^{\circ} \mathrm{C}, 35-60 \%$ relative humidity). The animals were treated strictly according to the CPCSEA guidelines and the study was conducted after obtaining permission from Institutional Animal Ethics Committee (IAEC).

\section{Acute Toxicity and Gross Behavioral Study}

The rats were fasted overnight, divided into groups $(n=6)$ and were orally fed with increasing doses $(250,500,750,1000 \mathrm{mg} / \mathrm{kg}$ body weight) of petroleum ether, methanol and aqueous extracts suspended in groundnut oil (arachis). After administration of the extracts, the animals were observed during first $2 \mathrm{~h}$ for their gross behavioral changes and once in 30 min for next $4 \mathrm{~h}$ and then once in $24 \mathrm{~h}$ for next $72 \mathrm{~h}$ to find out percentage mortality $[1,2,8]$.

\section{Assessment of In-Vivo \& In-Vitro Anti- Inflammatory Activity}

In the present investigation, the antiinflammatory activity of different extracts of leaves of Bixa orellana were tested by (chemical) carrageenan induced rat paw edema method using Diclofenac sodium as standard $[2,9,10]$ and in-vitro membrane stabilization of HRBCs [11,12].

\section{In-Vitro Anti-Inflammatory Activity Preparation of HRBCs (Human Red Blood Cells)}

Blood was collected from healthy human donors and centrifuged. The supernatant was then carefully pipetted with sterile pipettes. The packed cells were resuspended in an equal volume of isosaline and centrifuged. The process was repeated 4 times until the supernatants were clear. A $10 \%$ HRBC suspension was then prepared with normal saline and kept at $4^{\circ} \mathrm{C}$ until use.

\section{Effect of Plant Extracts on HRBC System}

The reaction mixture $(4.5 \mathrm{ml})$ consisted of $2 \mathrm{ml}$ hyposaline $(0.25 \% \mathrm{w} / \mathrm{v} \mathrm{NaCl}), 1 \mathrm{ml}$ of isosaline buffer solution, $\mathrm{P}^{\mathrm{H}} 7.4$ (6.0 g TRIS, $5.8 \mathrm{gm}$ $\mathrm{NaCl}, \mathrm{HCl}$ to regulate the $\mathrm{P}^{\mathrm{H}}$ and water to make $1000 \mathrm{ml}$ ) and varying volumes of the extract solution in isotonic buffer (concentration $=100$ $\mathrm{mg} / \mathrm{ml}$ ) to make the volume to $4.0 \mathrm{ml}$. Then $0.5 \mathrm{ml}$ of $10 \% \mathrm{HRBC}$ in normal saline was added. Two controls were performed. One control with $1 \mathrm{ml}$ of isosaline buffer instead of extract (control 1) and the other control with 1 ml of extract solution and without red blood cells (control 2). The mixture was incubated at $56^{\circ} \mathrm{C}$ for 30 mins. The tubes were cooled under running water for 20 mins. The mixture was centrifuged and the absorbance of the supernatant was read at $560 \mathrm{~nm}$. The percentage of membrane stabilization was determined using the formula:

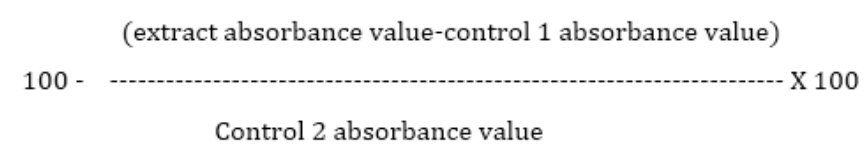

The control 1 represents 100\% HRBC lysis. The HRBC membrane stabilizing standard drug used was Diclofenac sodium.

\section{In-Vivo Anti-Inflammatory Activity}

Young adult male Wistar rats weighing 180$220 \mathrm{~g}$ were used which are acclimatized to the laboratory conditions and maintained on standard laboratory rat feed and clean water. Rats were fasted for $12 \mathrm{~h}$ prior to experiment, while allowing access to water throughout the experiment. Rats were divided 8 groups with each group containing 6 animals. The animals were administered control, standard or test extracts as shown in Table 1.

The control and standard samples were prepared in arachis oil. A mark was made on both the hind paws just beyond the tibiotarsal junction, so that every time the paw is dipped in the mercury column up to the marked level to ensure constant paw volume. After $1 \mathrm{~h}$ of administration of the test and standard samples, $0.1 \mathrm{ml}$ of $1 \%$ carrageenan suspension (in normal saline) was injected into dorsal region of sub plantar surface of hind paw of rat subcutaneously with the help of $26 \mathrm{G}$ needle. The initial paw volume of each rat was recorded before drug administration. The paw 
volumes were measured at the end of $0.5,1,2$, 3 and $4 \mathrm{~h}$ using plethysmometer. Any change in paw volume of rats was obtained by subtracting initial paw volume from the paw volumes at different time intervals. The average value of edema was calculated by taking the average of each group at different hours. Percentage inhibition of edema was calculated for each group with respect to its control group.

Percentage inhibition $=(\mathrm{A}-\mathrm{B}) \mathrm{x} 100 / \mathrm{A}$

Where $\mathrm{A}$ is the mean increase paw volume in rats treated with control and $\mathrm{B}$ is the mean increase in paw volume in rats treated with test.

\section{Analgesic Activity}

The analgesic activities of various extracts of leaves of Bixa orellana were evaluated by tail immersion method [8]. Young adult male Wistar rats weighing 180-220 g were taken and divided into eight groups with each group consists of six animals. The mice were held in position in a suitable restrainer with the tail extending out. 3-4 cm area of the tail was marked and immersed in the water bath thermostatically maintained at $55^{\circ} \mathrm{C}$. The tail flick latency which is defined as the time-lag between the application of heat from water bath and the withdrawal of the tail from hot water (in seconds), which was noted as the reaction time or tail flick latency. Before giving the drugs, basal reaction time to radiant heat was taken by placing the tip of the tail in the heat source (water bath at $55^{\circ} \mathrm{C}$ ). The tail withdrawal from the heat source (tail flicking response) was taken as the end point. Analgesics increase the reaction time. A cut off period of 15 secs was taken for preventing damage of tail of animal. Three basal reaction times for each mouse at a gap of 5 min were taken for the confirmation of the result. After observing the basal reaction time, the test extracts and standard drug were given orally in the form of arachis oil. Test extracts were studied at a dose of 250 and $500 \mathrm{mg} / \mathrm{kg}$ body weight. $100 \mathrm{mg} / \mathrm{kg}$ of paracetamol was used as standard. The reaction time was noted at 0,30 , 60, 120 and 180 mins after giving the drug/extract. The animals were administered control, standard and test extracts as shown in the Table 2. Tail flick latency difference or mean increase in latency after drug administration was used to indicate the analgesia produced by test and standard drugs.
Analgesia (tail flick latency difference) was calculated as follows.

Analgesia $=$ post-drug tail flick latency - predrug tail flick latency

\section{Results and Discussion}

In acute toxicity study, all the animals were found to be surviving after $72 \mathrm{~h}$. This indicates that the extracts were found to be safe up to the dose levels studied. Since, all the animals survived at a dose of $1000 \mathrm{mg} / \mathrm{kg}$ body weight, the $\mathrm{LD}_{50}$ of the extracts will be $>1000 \mathrm{mg} / \mathrm{kg}$ body weight. No major behavioral changes were observed during this period of study. The animals showed mild sedative effect upon administration of all the extracts Table 3 .

\section{Anti-Inflammatory Activity of Leaf Extracts of Bixa orellana}

\section{In-vitro}

Anti-inflammatory activity for all the leaf extracts was performed in-vitro by membrane stabilization of HRBCs at a dose of 3 and 5 $\mathrm{mg} / \mathrm{ml}$ (Figure 1). The results pertaining to this investigation were shown in the Table 4.

The results obtained in this investigation indicate that there was significant antiinflammatory activity for the petroleum ether extract. It showed about 67.47 percentage protection at a dose of $3 \mathrm{mg} / \mathrm{ml}$ and 37.3 percentage protection at a dose of $5 \mathrm{mg} / \mathrm{ml}$ indicating that the activity was dose independent. The methanolic extract and aqueous extracts showed less significant activity compared to that of petroleum ether extract.

\section{In-Vivo}

Anti-inflammatory activity for all the leaf extracts was performed in-vivo by carrageenan induced rat paw edema method at a dose of 250 and $500 \mathrm{mg} / \mathrm{Kg}$ body weight in rat. The results pertaining to this investigation were shown in Table 5 and Table 6 (Figure 2).

The results obtained in this investigation indicate that the percentage protection against 
edema formation with all extracts was significant and the extracts showed not dose dependent anti-inflammatory activity. From the Table 5 it can be observed that the standard drug Diclofenac sodium has protected to an extent of 30, 44.1, 64.1, 62.6 and $61.4 \%$ against inflammation induced by carrageenan at $1 / 2,1$, 2, 3 and $4 \mathrm{~h}$. Petroleum ether extract showed highest activity at dose level of $250 \mathrm{mg} / \mathrm{kg}$ at 2 h. Methanolic extract showed maximum activity at dose of $250 \mathrm{mg} / \mathrm{kg}$ at $3 \mathrm{~h}$. Aqueous extract has shown maximum activity at $2 \mathrm{~h}$.

\section{Analgesic Activity}

Screening for analgesic activity was performed for all the extracts at a dose of 250 and 500 $\mathrm{mg} / \mathrm{kg}$ body weight in rat. The evaluation was carried out by tail immersion method. This is a physical method involving application of heat and measuring the threshold of the animals to the painful stimuli. The results pertaining to this investigation are shown in the Table 7 and Figure 3.

All the extracts and standard showed dose dependent analgesic activity and have shown maximum effect at 120 min after administration. When compared with all other extracts, methanol extract showed maximum activity $(12.4 \mathrm{sec})$ at a dose of $500 \mathrm{mg} / \mathrm{kg}$ at 120 min after administration.

\section{Conclusion}

From the above results, it can be concluded that the In-vitro anti-inflammatory activity for the petroleum ether extract was significant of Bixa orellana leaves. In-vivo anti-inflammatory activity process significant effect by decreasing the edema with petroleum ether extract, which was produced by the carrageenan. Analgesic activity showed significant effect with methanolic extract. However, the activity was not comparable in terms of quantitative activity elicited by standard drug. This could be due to the use of crude extracts. Hence, isolation of active principles will be advantageous to produce novel bioactive constituents from these extracts which may possess more significant activity.

\section{References}

1. Kulkarni SK. Hand book of Experimental Pharmacology. $3^{\text {rd }}$ edition, Vallabprakasan 1999; 117-171.

2. Turner RA, Hebborn P. Screening methods in Pharmacology 2, Academic press 1971; 210-245.

3. Verdine GL. The combinatorial chemistry of nature, Nature 1996; 384: 11-13.

4. Castello MC, Pathak A, Chandra N, et al. Indian J Exp Biol 2002; 40: 1378-1381.

5. Aranez AT, Rubio RO. Genotoxicity of pigments from seeds of Bixa orellana (Astute) I determined by Allium test. Philipp J Sci 1996; 125: 259-269.

6. Shilpi A, Taufiq-Ur-Rahman M, Uddin SJ, et al. Preliminary pharmacological screening of Bixa orellana. J Ethnopharmacol 2006; 108: 264-271.

7. Bruneton J. Pharmacognosy, Phytochemistry of Medicinal Plants. $2^{\text {nd }}$ Ed, Intercept 1999; 131-160.

8. Amos B, Adzu L, Binda $\mathrm{CW}$, et al. Behavioral effects of the aqueous extract of Guiera senegalensisi in mice and rats. Phytomedicine 2001; 8: 356-361.

9. Ahmed F, Khan RA. Study of Analgesic and Anti-inflammatory activity from Plant extracts of Lactuca scariola and Artemisia absinthium. Pak J Islam Acad Sci 1992; 5: 111-114.

10. Dimo T, Fotio AL, Nguelefack TB, et al. Anti-inflammatory activity of leaf extracts of Kalanchoe crenata Andr. Indian J Pharmacol 2006; 38: 115-119.

11. Divakar MC, Jayaprakasham R. Antiinflammatory and free radical activities of sea cucumber and cuttle fish glandular extracts. Indian drugs 2006; 43: 471- 475.

12. Mongeli E, Desmarchelier C, Coussio J, et al. Biological studies of Bolax gummifera, a plant of the falkland islands used as a treatment of wounds. J Ethnopharmacol 1997; 56: 117-121. 


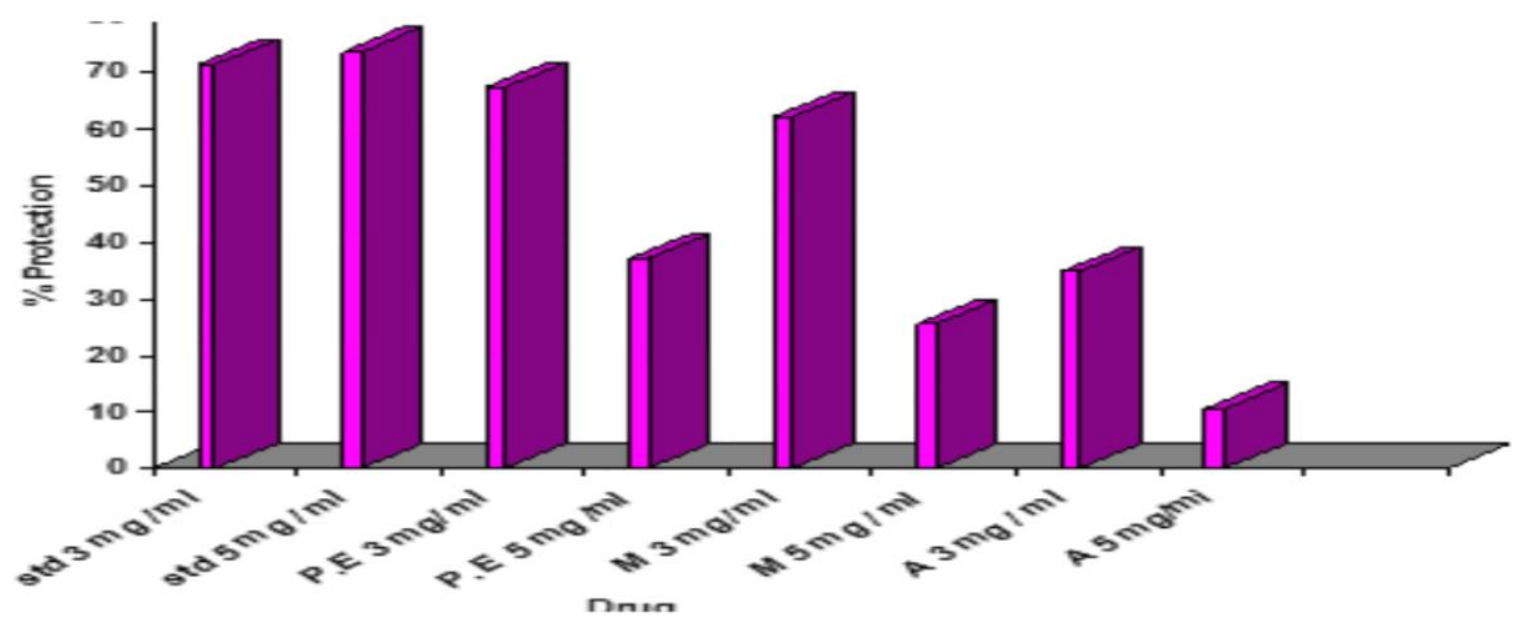

Figure 1: Percentage protection of leaf extracts of Bixa orellana on membrane stabilization of HRBCs
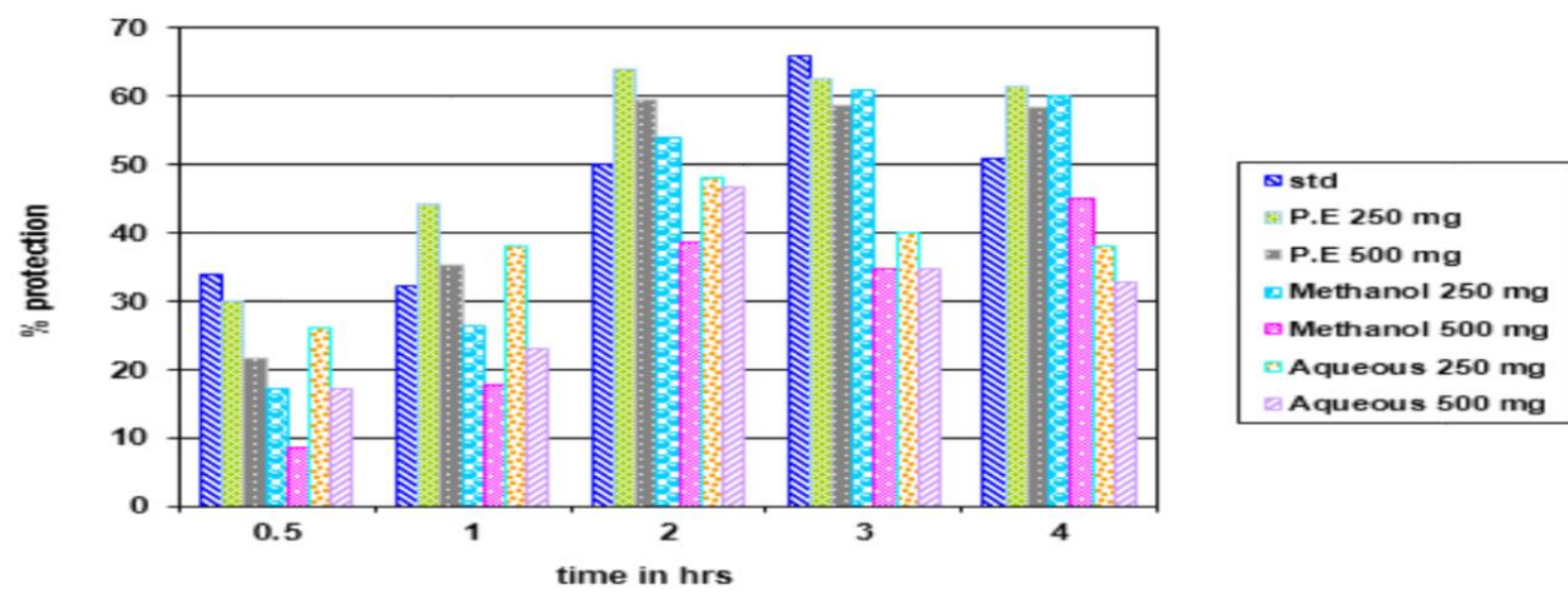

Figure 2: Percentage protection of leaf extracts of Bixa orellana against edema formation

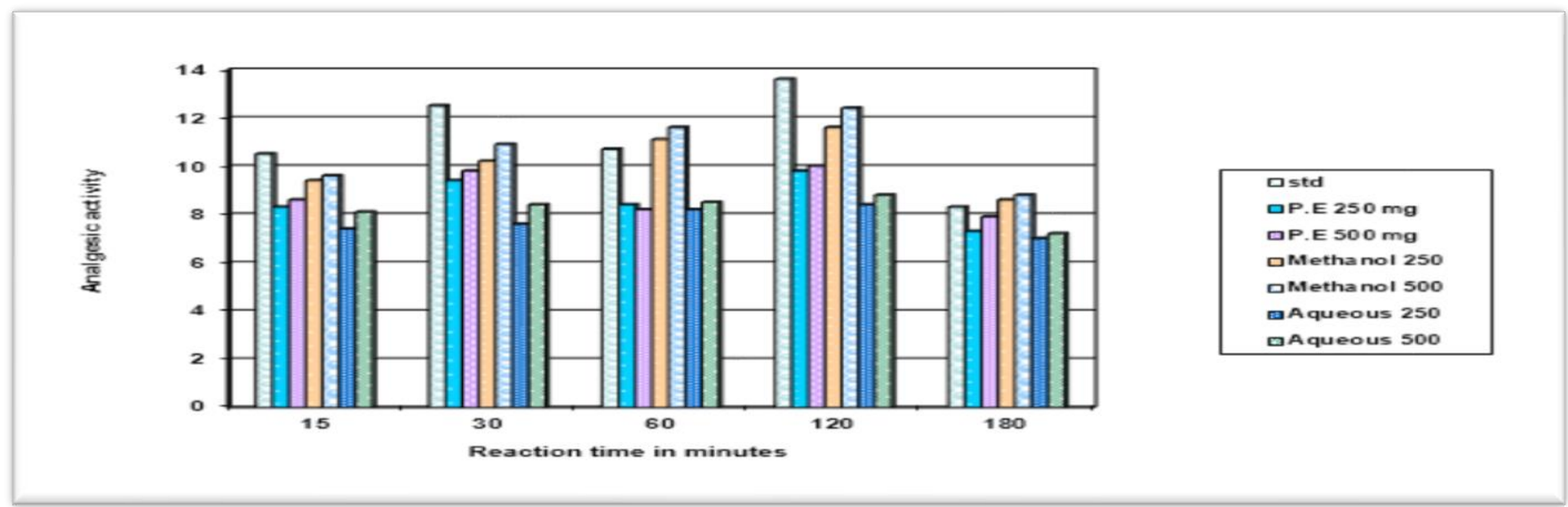

Figure 3: Analgesic activity of leaf extracts of Bixa orellana 
Table 1: Division of animals for anti-inflammatory activity of Bixa orellana

\begin{tabular}{|l|l|}
\hline \multicolumn{1}{|c|}{ Group } & \multicolumn{1}{c|}{ Extract } \\
\hline Group I (Control) & Arachis oil \\
\hline Group II (Standard) & Diclofenac sodium $(100 \mathrm{mg} / \mathrm{kg})$ \\
\hline Group III & Petroleum ether extract $(250 \mathrm{mg} / \mathrm{kg})$ \\
\hline Group IV & Petroleum ether extract $(500 \mathrm{mg} / \mathrm{kg})$ \\
\hline Group V & Methanolic extract $(250 \mathrm{mg} / \mathrm{kg})$ \\
\hline Group VI & Methanolic extract $(500 \mathrm{mg} / \mathrm{kg})$ \\
\hline Group VII & Aqueous extract $(250 \mathrm{mg} / \mathrm{kg})$ \\
\hline Group VIII & Aqueous extract $(500 \mathrm{mg} / \mathrm{kg})$ \\
\hline
\end{tabular}

Table 2: Division of animals for Analgesic activity of Bixa orellana leaf extracts

\begin{tabular}{|l|l|}
\hline \multicolumn{1}{|c|}{ Group } & \multicolumn{1}{c|}{ Extract } \\
\hline Group I (Control) & Arachis oil \\
\hline Group II (Standard) & Paracetamol $(100 \mathrm{mg} / \mathrm{kg})$ \\
\hline Group III & Petroleum ether extract $(250 \mathrm{mg} / \mathrm{kg})$ \\
\hline Group IV & Petroleum ether extract $(500 \mathrm{mg} / \mathrm{kg})$ \\
\hline Group V & methanolic extract $(250 \mathrm{mg} / \mathrm{kg})$ \\
\hline Group VI & methanolic extract $(500 \mathrm{mg} / \mathrm{kg})$ \\
\hline Group VII & Aqueous extract $(250 \mathrm{mg} / \mathrm{kg})$ \\
\hline Group VIII & Aqueous extract $(500 \mathrm{mg} / \mathrm{kg})$ \\
\hline
\end{tabular}

Values for analgesic activity were expressed as "mean increase in latency after drug administration \pm SEM" in terms of second

Table 3: Acute toxicity studies

\begin{tabular}{|c|c|c|c|c|c|}
\hline Extracts & Group & Dose(mg/kg) & $\begin{array}{l}\text { No of mice } \\
\text { each group }\end{array}$ & After 4 hours & After 24 hours \\
\hline \multirow{4}{*}{$\begin{array}{c}\text { Petroleum } \\
\text { ether }\end{array}$} & $\mathrm{I}$ & 250 & 6 & 6 & 6 \\
\hline & II & 500 & 6 & 6 & 6 \\
\hline & III & 750 & 6 & 6 & 6 \\
\hline & IV & 1000 & 6 & 6 & 6 \\
\hline \multirow{4}{*}{ Methanol } & $\mathrm{I}$ & 250 & 6 & 6 & 6 \\
\hline & II & 500 & 6 & 6 & 6 \\
\hline & III & 750 & 6 & 6 & 6 \\
\hline & IV & 1000 & 6 & 6 & 6 \\
\hline
\end{tabular}




\begin{tabular}{|c|c|c|c|c|c|}
\hline \multirow{3}{*}{ aqueous } & I & 250 & 6 & 6 & 6 \\
\cline { 2 - 6 } & II & 500 & 6 & 6 & 6 \\
\cline { 2 - 6 } & III & 750 & 6 & 6 & 6 \\
\cline { 2 - 6 } & IV & 1000 & 6 & 6 & 6 \\
\hline
\end{tabular}

Table 4: In-vitro Anti-inflammatory activity

\begin{tabular}{|c|c|c|}
\hline Treatment & Dose $\mathbf{~ m g} / \mathbf{m l}$ & \%Protection \\
\hline \multirow{2}{*}{ Standard } & 3 & 72.04 \\
\cline { 2 - 3 } & 5 & 75.01 \\
\hline \multirow{2}{*}{ Petroleum ether } & 3 & 67.47 \\
\cline { 2 - 3 } & 5 & 37.35 \\
\hline Methanol & 3 & 62.3 \\
\cline { 2 - 3 } & 5 & 25.6 \\
\hline \multirow{2}{*}{ Aqueous } & 3 & 34.99 \\
\hline
\end{tabular}

Table 5: Anti-inflammatory activity of leaf extracts of Bixa orellana

\begin{tabular}{|c|c|c|c|c|c|c|}
\hline \multirow{2}{*}{$\begin{array}{l}\text { Name of } \\
\text { the drug }\end{array}$} & \multirow{2}{*}{$\begin{array}{l}\text { Dose } \\
(\mathrm{mg} / \mathrm{kg})\end{array}$} & \multicolumn{5}{|c|}{ *Mean Edema Volume (ml) } \\
\hline & & $30 \mathrm{~min}$ & $1 \mathrm{~h}$ & $2 \mathrm{~h}$ & $3 \mathbf{h}$ & $4 \mathrm{~h}$ \\
\hline Control & - & $\begin{array}{c}0.23 \pm \\
0.02\end{array}$ & $0.34 \pm 0.02$ & $0.62 \pm 0.05$ & $0.75 \pm 0.02$ & $0.70 \pm 0.03$ \\
\hline $\begin{array}{l}\text { Standard } \\
\text { (Diclofenac } \\
\text { sodium) }\end{array}$ & 100 & $\begin{array}{c}0.15 \pm \\
0.03\end{array}$ & $0.23 \pm 0.03$ & $0.31 \pm 0.03$ & $0.27 \pm 0.04$ & $0.34 \pm 0.03$ \\
\hline \multirow{2}{*}{$\begin{array}{l}\text { Petroleum } \\
\text { ether }\end{array}$} & 250 & $\begin{array}{c}0.16 \pm \\
0.02\end{array}$ & $0.19 \pm 0.03$ & $0.21 \pm 0.05$ & $0.28 \pm 0.04$ & $0.27 \pm 0.04$ \\
\hline & 500 & $\begin{array}{c}0.18 \pm \\
0.02\end{array}$ & $0.22 \pm 0.03$ & $0.25 \pm 0.02$ & $0.31 \pm 0.03$ & $0.29 \pm 0.03$ \\
\hline \multirow[t]{2}{*}{ Methanol } & 250 & $\begin{array}{c}0.19 \pm \\
0.01\end{array}$ & $0.25 \pm 0.03$ & $0.28 \pm 0.03$ & $0.29 \pm 0.05$ & $0.28 \pm 0.06$ \\
\hline & 500 & $\begin{array}{c}0.21 \pm \\
0.03\end{array}$ & $0.28 \pm 0.04$ & $0.38 \pm 0.03$ & $0.49 \pm 0.04$ & $0.38 \pm 0.04$ \\
\hline
\end{tabular}




\begin{tabular}{|l|c|c|c|c|c|c|}
\hline \multirow{3}{*}{ Aqueous } & 250 & $0.27 \pm$ & $0.21 \pm 0.03$ & $0.32 \pm 0.03$ & $0.45 \pm 0.04$ & $0.43 \pm 0.03$ \\
& & 0.02 & & & & \\
\cline { 2 - 7 } & 500 & $0.19 \pm$ & $0.26 \pm 0.04$ & $0.33 \pm 0.03$ & $0.49 \pm 0.04$ & $0.47 \pm 0.05$ \\
& & 0.03 & & & & \\
\hline
\end{tabular}

Note: * indicates Edema volume (mean \pm SEM)

Table 6: Percentage protection against edema formation

\begin{tabular}{|c|c|c|c|c|c|c|}
\hline \multirow[t]{2}{*}{ Name of the drug } & \multirow{2}{*}{$\begin{array}{l}\text { Dose } \\
\text { (mg/kg) }\end{array}$} & \multicolumn{5}{|c|}{$\%$ Protection } \\
\hline & & $30 \mathrm{~min}$ & $\mathbf{1 h}$ & $2 \mathrm{~h}$ & $3 \mathbf{h}$ & $4 \mathrm{~h}$ \\
\hline Standard & 100 & 34 & 32.3 & 50 & 66 & 51 \\
\hline \multirow[t]{2}{*}{ Petroleum ether } & 250 & 30 & 44.1 & 64.1 & 62.6 & 61.4 \\
\hline & 500 & 21.7 & 35.2 & 59.6 & 58.6 & 58.5 \\
\hline \multirow[t]{2}{*}{ Methanol } & 250 & 17.3 & 26.4 & 54 & 61 & 60 \\
\hline & 500 & 8.6 & 17.6 & 38.7 & 34.6 & 45 \\
\hline \multirow[t]{2}{*}{ aqueous } & 250 & 26 & 38.2 & 48 & 40 & 38 \\
\hline & 500 & 17.3 & 23 & 46.7 & 34.6 & 32.8 \\
\hline
\end{tabular}

Table 7: Analgesic activity of leaf extracts of Bixa orellana

\begin{tabular}{|c|c|c|c|c|c|c|}
\hline \multirow[t]{2}{*}{ Name of the drug } & \multirow[t]{2}{*}{ Dose (mg/kg) } & \multicolumn{5}{|c|}{ Mean Reaction Time in Seconds } \\
\hline & & $15 \mathrm{~min}$ & $30 \mathrm{~min}$ & $60 \mathrm{~min}$ & $120 \mathrm{~min}$ & $180 \mathrm{~min}$ \\
\hline Control & - & $3.33 \pm 0.22$ & $4.33 \pm 0.21$ & $4.0 \pm 0.25$ & $4.16 \pm 0.16$ & $3.5 \pm 0.22$ \\
\hline Standard & 100 & $10.5 \pm 0.21$ & $12.5 \pm 0.30$ & $10.7 \pm 0.26$ & $13.6 \pm 0.22$ & $8.3 \pm 0.33$ \\
\hline \multirow[t]{2}{*}{ Petroleum ether } & 250 & $8.3 \pm 0.06$ & $9.4 \pm 0.25$ & $8.4 \pm 0.33$ & $9.8 \pm 0.33$ & $7.3 \pm 0.16$ \\
\hline & 500 & $8.6 \pm 0.07$ & $9.8 \pm 0.22$ & $8.2 \pm 0.42$ & $10.0 \pm 0.43$ & $7.9 \pm 0.33$ \\
\hline \multirow[t]{2}{*}{ Methanol } & 250 & $9.4 \pm 0.30$ & $10.2 \pm 0.16$ & $11.1 \pm 0.22$ & $11.6 \pm 0.42$ & $8.6 \pm 0.22$ \\
\hline & 500 & $9.6 \pm 0.40$ & $10.9 \pm 0.40$ & $11.6 \pm 0.42$ & $12.4 \pm 0.22$ & $8.8 \pm 0.16$ \\
\hline \multirow[t]{2}{*}{ Aqueous } & 250 & $7.4 \pm 0.26$ & $7.6 \pm 0.40$ & $8.2 \pm 0.2$ & $8.4 \pm 0.33$ & $7.0 \pm 0.21$ \\
\hline & 500 & $8.1 \pm 0.42$ & $8.4 \pm 0.21$ & $8.5 \pm 0.25$ & $8.8 \pm 0.34$ & $7.2 \pm 0.34$ \\
\hline
\end{tabular}


This manuscript was peer-reviewed

Mode of Review: Single-blinded

\section{Editor: Dr. Sabrin R. M. Ibrahim}

International Journal of Pharmaceutics and Pharmacology is an open access, peer reviewed journal published by Edwiser International.

Submit your valuable manuscript at-

editor.ijpp@edwiserinternational.com

submit.manuscript@edwiserinternational.com

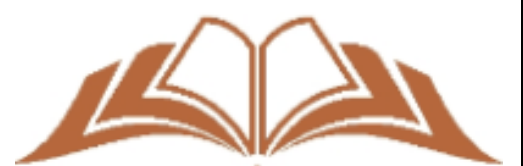

EDW $\mathrm{D}$ S E R
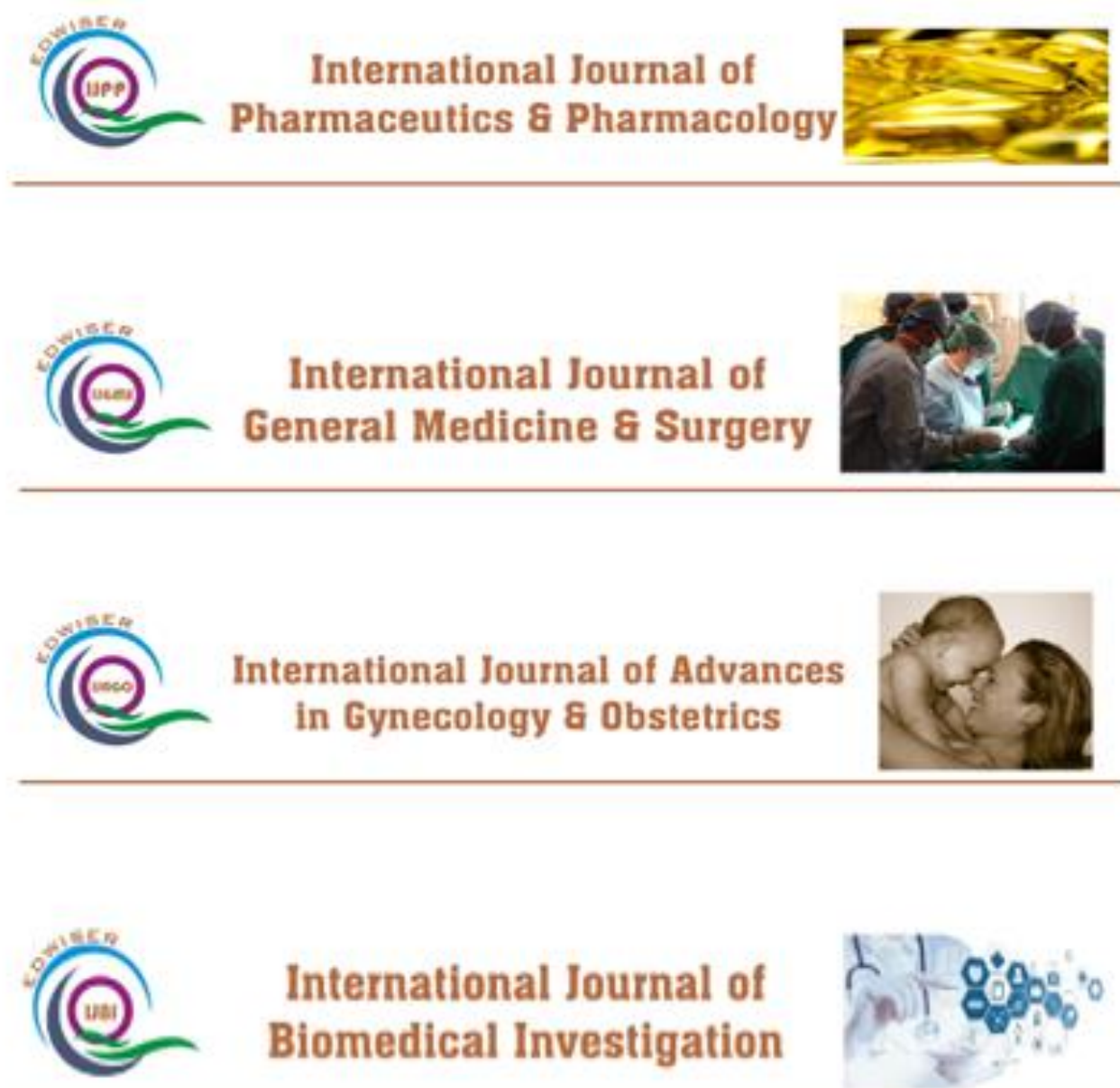

\section{International Journal of Biomedical Investigation}
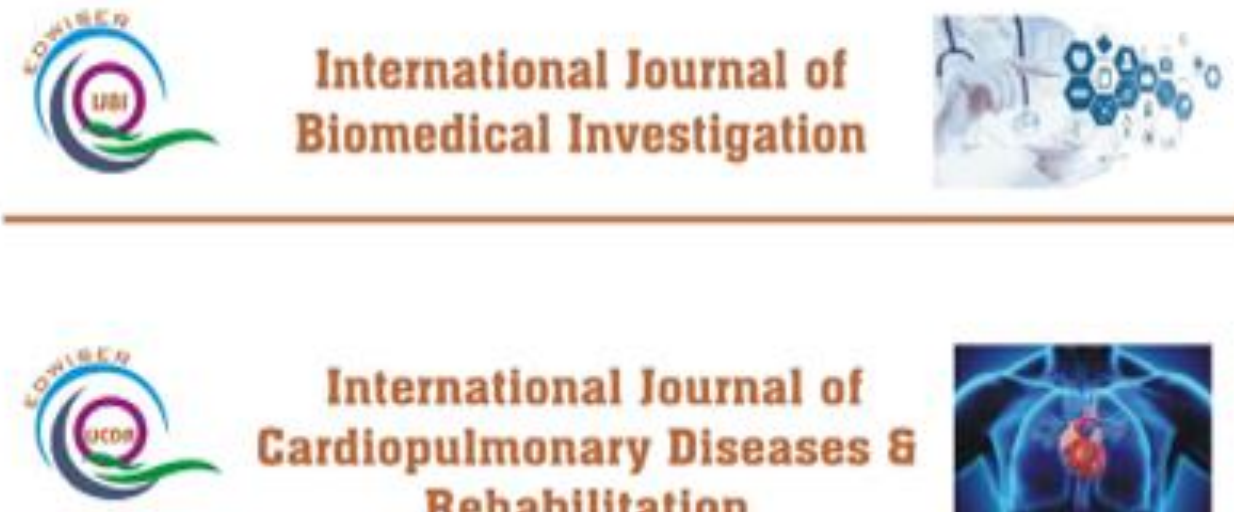

International Journal of Cardiopulmonary Diseases \& Rehabilitation

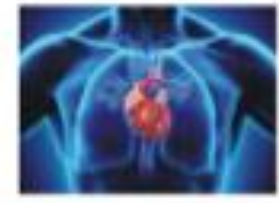

